in smoking habits and did not show evidence of airway obstruction. A smaller proportion of reactors than non-reactors were bronchitic, but this apparent difference may well have been due to chance $\left(\chi^{2}=2 \cdot 18, \mathrm{P}>0 \cdot 2\right)$.

For various reasons it was possible to study only 19 of the 24 reactors during the second week. Fifteen of the 19 had no abnormal respiratory symptoms and had normal values for F.E.V.,/V.C. \%, one had simple chronic bronchitis with a normal value of F.E.V.'/V.C. \%, and three had values for F.E.V. 1 /V.C. $\%$ which were less than $70 \%$ but did not have symptoms of bronchitis. All 19 had normal values for SGaw before smoking.

The comparison of the reaction to cigarettes $\mathrm{X}, \mathrm{Y}$, and $\mathrm{Z}$ is presented in Fig. 1. The statistical details are shown in Table II. There were significant differences in the reaction between $\mathrm{X}$ and $\mathrm{Y}$ and between $\mathrm{X}$ and $\mathrm{Z}$ but not between $\mathrm{Y}$ and $\mathrm{Z}$.

\begin{tabular}{|c|c|c|c|c|c|}
\hline $\begin{array}{c}\text { Cigar- } \\
\text { ette }\end{array}$ & $\begin{array}{c}\text { Retention } \\
\text { Efficiency } \\
\text { of filter }\end{array}$ & $\begin{array}{l}\text { Type of } \\
\text { tobacco }\end{array}$ & $\begin{array}{c}\text { Mean } \\
\text { change in } \\
\text { Log SGaw }\end{array}$ & $\begin{array}{c}\text { Difference } \\
\text { between } \\
\text { means and } \\
\text { S.E. of } \\
\text { differences }\end{array}$ & Values of $t$ and $P$ \\
\hline $\begin{array}{l}\mathrm{Y} \\
\mathrm{X} \\
\mathrm{Z}\end{array}$ & $\begin{array}{l}27 \% \\
50 \% \\
36 \%\end{array}$ & $\begin{array}{l}\text { Cigarette } \\
\text { Cigarette } \\
\text { Cigar }\end{array}$ & $\begin{array}{l}-0.17 ! \\
-0.10 \\
0-.21\end{array}$ & $\begin{array}{l}0.07 \pm 0.02 \\
0.11 \pm 0.03\end{array}$ & $\begin{array}{l}\mathrm{t}^{*}=2.5,0.01<\mathrm{P}<0.05 \\
\mathrm{t}^{*}=3.9, \mathrm{P}<0.01\end{array}$ \\
\hline
\end{tabular}

Fig. 2 shows the average changes in log SGaw in three reactors after 5, 10, and 15 puffs of smoke from each of the three different cigarettes. The results in four reactors of the repeated measurements at half and one hour after stopping smoking cigarette $\mathrm{Y}$ appear in Fig. 3.

\section{Discussion}

In a comparison of the reaction produced by various cigarettes it is essential to standardize the dose of smoke to which each subject is exposed. After considering the use of spirometers and other apparatus for fixing the inhaled dose we decided that the technique described above was the most practicable. In order to standardize the dose it was necessary to impose an unaccustomed method of smoking on our subjects.
The use of a total dose of 10 puffs of smoke was suggested by preliminary studies and confirmed by the dose-response studies here reported, in which it was found to produce a maximal change in SGaw for cigarettes $\mathrm{X}$ and $\mathrm{Y}$; but for cigarette $Z$ the dose may have caused us to underestimate the reaction (Fig. 2).

The duration-response studies showed that SGaw returns rapidly to baseline after smoking stops. For this reason measurements were made two minutes after smoking had finished.

Our results indicate that reactivity to cigarette smoke is reduced significantly by increasing the retention efficiency of the filter. Cigarette $Z$, which contained cigar tobacco, produced a bronchial reaction similar to that of cigarette $\mathrm{Y}$ despite the fact that it had a filter with a greater retention efficiency. In practice, however, cigar tobacco smoke is less often inhaled and so may have less effect on airway resistance.

We consider the degree of airway obstruction resulting from tobacco smoke in these healthy prisoners to be undesirable irrespective of its possible relationship to the development of bronchial disease. Since the effect of filters is to reduce this bronchial reactivity their use may be beneficial, but our results, of course, have no bearing on the carcinogenic effect of tobacco smoke.

Our thanks are due to the Home Office for permission to perform this work, and to the prison officers and medical officers, in particular Dr. H. W. Eldridge, of Wormwood Scrubs Prison, for their help. Statistical advice was provided by Mr. M. Healy, of the Medical Research Council, Clinical Research M Centre. The computer was programmed and run by Miss Helen Pope. We are also grateful to Dr. L. E. Kagle and Dr. A. Raimondi for their help during the experiment.

\section{REFERENCES}

DuBois, A. B., Botelho, S. Y., Bedell, G. N., Marshall, R., and Comroe, J. H. (1956a). Fournal of Clinical Investigation, 35, 322.

DuBois, A. B., Botelho, S. Y., and Comroe, J. H. (1956b). Fournal of Clinical Investigation, 35, 327.

Guyatt, A. R., and Alpers, J. H. (1968). Fournal of Applied Physiology, 24, 310 .

Guyatt, A. R., Alpers, J. H., and Davies, E. E. (1967). fournal of Applied Physiology, 22, 390.

McDermott, M., and Collins, M. M. (1965). Thorax, 20, 562.

Medical Research Council (1966). Questionnaire on Respiratory Symptoms, obtainable from W. J. Holman Ltd., Dawlish, Devonshire.

\title{
Acid-base Status of Adults with Sickle-cell Anaemia
}

\author{
H. HO PING KONG,* M.B.; G. A. O. ALLEYNE, $†$ M.D., M.R.c.P.
}

\begin{abstract}
Summary : Determinations of the acid-base status of 10 $\checkmark$ adult Jamaican patients with sickle-cell anaemia during "painful crisis" and after recovery showed no evidence of metabolic acidosis in the former, in contrast to reports from elsewhere. These results could explain the failure of alkalis to abort or alter the acute painful episodes of most patients with sickle-cell anaemia.
\end{abstract}

\section{Introduction}

The aetiology and treatment of the acute painful episodes ("painful crises") remain one of the major problems in patients with sickle-cell anaemia. The excruciating pains in the back, abdomen, chest, and limbs, accompanied by fever, have been well described (Diggs, 1965). Metabolic acidosis has been incriminated as the initiating cause of these painful crises (Diggs, 1965), and a report of 17 consecutive cases in painful crisis has noted that a severe metabolic acidosis was consistently present (Barreras and Diggs, 1964). It is also known that painful crises can be produced experimentally by the prolonged administration of ammonium chloride (Greenberg et al., 1957; Barreras and Diggs, 1964). As a result, the use of alkalis for the treatment and prevention of painful crises has been universally advocated (Greenberg et al., 1957 ; Greenberg and Kass, 1958 ; Nwokolo, 1960 ; Barreras and Diggs, 1964 ; Hugh-

* Wellcome Trust Grant Holder.

†ember of Scientific Staff.

Medical Research Council Tropical Metabolism Research Unit, University of the West Indies, Kingston 7, Jamaica. 
Jones et al., 1964). Our experience in Jamaica, however, has made it clear that treatment with alkalis does little to abort or shorten the duration of the painful crises. The present study was therefore designed to study acid-base factors in the steady state and during painful crises.

\section{Methods}

Acid-base Studies in the Steady State.-The blood $p \mathrm{H}$, total $\mathrm{CO}_{2}$, and $\mathrm{PCO}_{2}$ were measured on 60 occasions in 31 patients with sickle-cell anaemia (all had haemoglobin electrophoresis SS) when they were free of pain or fever. Thirty-one normal controls were studied for comparison. All subjects were rested quietly for 10 minutes, and then venous blood was drawn without stasis from one of the antecubital veins into a heparinized syringe. The blood $\mathrm{pH}$ was immediately determined with an Astrup micro-assembly and the plasma total $\mathrm{CO}_{2}$ with a Natelson microgasometer. The $\mathrm{PCO}_{2}$ was calculated from the Henderson-Hasselbach equation.

Table I.-Admission Data for 10 Patients During 11 Acute Painful

\begin{tabular}{|c|c|c|c|c|c|c|}
\hline $\begin{array}{l}\text { Case } \\
\text { No. }\end{array}$ & Age & Sex & $\begin{array}{l}\text { Haemoglobin } \\
\text { Electrophoresis }\end{array}$ & $\underset{(\mathrm{g} . / 100 \mathrm{ml} .)}{\mathrm{Hb}}$ & $\begin{array}{l}\text { W.B.C. } \\
\text { (Cells/Cu. } \\
\text { mm.) }\end{array}$ & $\begin{array}{c}\text { Alkaline } \\
\text { Phosphatase } \\
\text { (K. A. Units) }\end{array}$ \\
\hline $\begin{array}{r}1 \\
2 \\
3 \\
4 \\
5 \\
6 \\
7 \\
8 \\
9 \\
10\end{array}$ & $\begin{array}{l}19 \\
16 \\
12 \\
12 \\
21 \\
15 \\
20 \\
14 \\
29 \\
13\end{array}$ & $\begin{array}{l}\mathbf{F} \\
\mathbf{F} \\
\mathbf{F} \\
\mathbf{F} \\
\mathbf{M} \\
\mathbf{M} \\
\mathbf{M} \\
\mathbf{M} \\
\mathbf{M} \\
\mathbf{M}\end{array}$ & $\begin{array}{l}\text { SS } \\
\text { SS } \\
\text { SS } \\
\text { SS } \\
\text { SS } \\
\text { SS } \\
\text { SS } \\
\text { SS } \\
\text { SS } \\
\text { SC }\end{array}$ & $\begin{array}{r}5 \cdot 7 \\
9 \cdot 2 \\
9 \cdot 1 \\
9 \cdot 2 \\
9 \cdot 3 \\
8 \cdot 3 \\
7 \cdot 8 \\
7 \cdot 2 \\
9 \cdot 5 \\
7 \cdot 4 \\
10 \cdot 7\end{array}$ & $\begin{array}{r}12, \overline{000} \\
16,700 \\
20,800 \\
14,700 \\
13,900 \\
24,500 \\
17,100 \\
14,100 \\
9,800\end{array}$ & $\begin{array}{l}-28 \\
19 \\
26 \\
15 \\
20 \\
22 \\
9 \\
20 \\
16 \\
31\end{array}$ \\
\hline
\end{tabular}

Acid-base Status during Painful Crisis.-Ten patients aged 12 to 29 were studied during 11 acute episodes. Some of their admission data are presented in Table I. The criteria for admission were (a) pains in back, limbs, chest, or abdomen severe enough to require admission to hospital, and $(b)$ fever of $100^{\circ}$ F. $\left(37 \cdot 8^{\circ}\right.$ C.) or over. Great care was taken to ensure that the patients admitted to the study were not taking any medications which might significantly affect their acid-base status. Treatment consisted of supportive and symptomatic measures only. All patients required pethidine for pain at some time during their admission. Less severe pain was treated with paracetamol. Full hydration was maintained by large quantities of oral fluid. None of the patients were given aspirin or sodium bicarbonate during the course of this study. A patient was considered to be out of "crisis" when he stopped having significant pains. This was usually accompanied by a fall in temperature. All patients made uneventful recoveries. The first six patients studied had their blood $\mathrm{pH}$, total $\mathrm{CO}_{2}$, and $\mathrm{PCO}_{2}$ determined on admission. This procedure was repeated when they had recovered. The last five patients were studied in more detail. Blood $\mathrm{pH}$, total $\mathrm{CO}_{2}$, and $\mathrm{PCO}_{2}$ were measured on admission and repeated daily for the duration of the painful crisis. These measurements were then continued for an equal number of days on their recovery.

\section{Results}

Acid-base Status in the Steady State.-The results show that patients with sickle-cell anaemia in the steady state have a mild respiratory alkalosis. When compared with the normal controls they were found to have a slightly higher blood $\mathrm{pH}$ and lower total $\mathrm{CO}_{2}$ and $\mathrm{PCO}_{2}$. The results are summarized in Table II.

Acid-base Status during Painful Crisis.-The results of the acid-base studies during painful crisis showed no evidence of metabolic acidosis. The mean values and the results of the 11 acute episodes are presented in Table III. The daily blood
$\mathrm{pH}$, total $\mathrm{CO}_{2}$, and $\mathrm{PCO}_{2}$ results of the two patients with the severest symptoms are presented in Figs. 1 and 2 . Again it is clearly shown that there was no evidence of metabolic acidosis during painful crisis in either patient.

\begin{tabular}{|c|c|c|c|c|c|}
\hline & & No. & $p \mathrm{H}$ & $\begin{array}{l}\text { Total } \mathrm{CO}_{2} \\
(\mathrm{mEq} / \mathrm{l} .)\end{array}$ & $\mathrm{PCO}_{2}(\mathrm{~mm} . \mathrm{Hg})$ \\
\hline $\begin{array}{l}\text { Sickle-cell } \\
\text { Anaemia } \\
\text { Controls }\end{array}$ & $\because$ & $\begin{array}{l}60 \\
31\end{array}$ & $\begin{array}{l}7.371 \pm 0.020^{*} \\
7.355 \pm 0.025\end{array}$ & $\begin{array}{l}26 \cdot 0 \pm 1 \cdot 4 \\
27 \cdot 3 \pm 1 \cdot 9\end{array}$ & $\begin{array}{l}44 \pm 3 \\
48 \pm 4\end{array}$ \\
\hline & & & $P<0.005 t$ & $P<0.005$ & $P<0.001$ \\
\hline
\end{tabular}

* Mean \pm S.D.

+ Hydrogen-ion concentrations were calculated, followed by the differences between the means by use of Student's $t$ test.

TABLe III.-Acid-Base Status During Painful Crisis

\begin{tabular}{|c|c|c|c|c|c|c|}
\hline \multirow[b]{2}{*}{$\begin{array}{l}\text { Case } \\
\text { No. }\end{array}$} & \multicolumn{3}{|c|}{ Painful Crisis } & \multicolumn{3}{|c|}{ Recovered } \\
\hline & $p \mathrm{H}$ & $\underset{(\mathrm{mEq} / \mathrm{l} .)}{\text { Total } \mathrm{CO}_{2}}$ & $\begin{array}{c}\mathrm{PcO}_{2} \\
(\mathrm{~mm} . \\
\mathrm{Hg})\end{array}$ & $p \mathrm{H}$ & $\underset{(\mathrm{mEq} / 1 .)}{\text { Total } \mathrm{CO}_{2}}$ & $\begin{array}{c}\mathrm{PCO}_{2} \\
(\mathrm{~mm} . \\
\mathrm{Hg})\end{array}$ \\
\hline $\begin{array}{r}1 \\
2 \\
3 \\
4 \\
5 \\
6 \\
7 \\
8 \\
9 \\
10\end{array}$ & $\begin{array}{l}7 \cdot 36 \\
7 \cdot 39 \\
7 \cdot 36 \\
7 \cdot 37 \\
7 \cdot 40 \\
7 \cdot 36 \\
7 \cdot 39 \\
7 \cdot 40 \\
7 \cdot 44 \\
7 \cdot 45 \\
7 \cdot 46\end{array}$ & $\begin{array}{l}29 \cdot 6 \\
23.4 \\
23.0 \\
23.6 \\
24 \cdot 0 \\
23.9 \\
29 \cdot 0 \\
27.5 \\
26.9 \\
23.6 \\
26.7\end{array}$ & $\begin{array}{l}51 \\
38 \\
40 \\
41 \\
38 \\
42 \\
47 \\
44 \\
39 \\
34 \\
37\end{array}$ & $\begin{array}{l}\mathbf{7} \cdot 37 \\
\mathbf{7} \cdot 36 \\
\mathbf{7} \cdot 37 \\
\mathbf{7} \cdot 39 \\
\mathbf{7} \cdot 36 \\
\mathbf{7} \cdot 37 \\
\mathbf{7} \cdot 39 \\
\mathbf{7} \cdot 39 \\
\mathbf{7} \cdot 39 \\
\mathbf{7} \cdot 37 \\
\mathbf{7} \cdot 44\end{array}$ & $\begin{array}{l}26 \cdot 8 \\
25 \cdot 9 \\
22 \cdot 6 \\
23 \cdot 2 \\
26 \cdot 6 \\
26 \cdot 7 \\
25 \cdot 4 \\
25 \cdot 3 \\
25 \cdot 8 \\
29 \cdot 9 \\
29 \cdot 4\end{array}$ & $\begin{array}{l}45 \\
45 \\
38 \\
38 \\
46 \\
45 \\
41 \\
41 \\
42 \\
51 \\
43\end{array}$ \\
\hline $\begin{array}{r}\text { Mean } \\
\pm \text { S.D. }\end{array}$ & $7 \cdot 40 \pm 0.04$ & $25 \cdot 6 \pm 2 \cdot 0$ & $41 \pm 5$ & $7.38 \pm 0.04$ & $26 \cdot 1 \pm 2 \cdot 7$ & $43 \pm 5$ \\
\hline
\end{tabular}

Figure 1
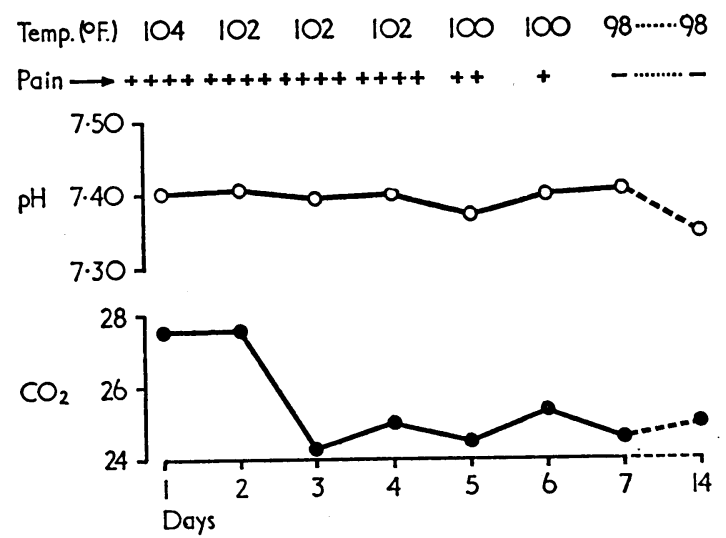

Fig. 1.-Daily blood $\mathrm{pH}$ and total $\mathrm{CO}_{2}, \mathrm{mEq} / \mathrm{l}$.) in relation to pains and fever are shown for patient (Case 7), who had the most severe "crisis" in this series.

\section{Figure 2}

$\begin{array}{lllllllll}\text { Temp. (PF.) } & 101 & 102 & 102 & 102 & 101 & 100 & 98 & 98\end{array}$ Pain $\longrightarrow+++++++++$ + + - -
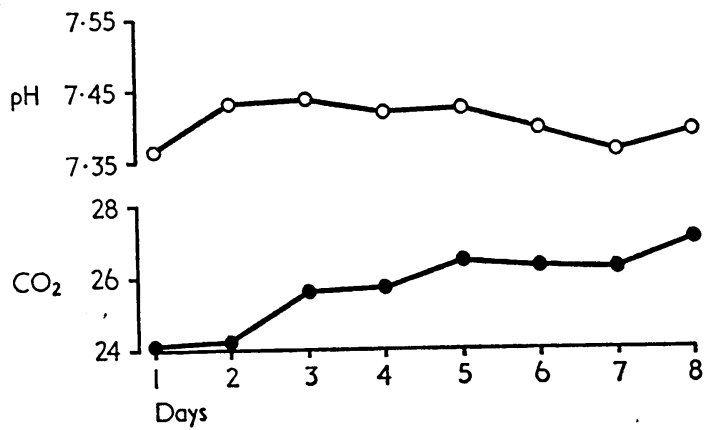

FIG. 2.-Daily blood $\mathrm{pH}$ and total $\mathrm{CO}_{2}(\mathrm{mEq} / \mathrm{l}$.) in relation to pains and fever are shown for Case 6. 


\section{Discussion}

The patients in this series were typical of the patients admitted to our hospital for the treatment of painful crisis. The finding of a mild respiratory alkalosis during the steady state is interesting, but is not specific for sickle-cell anaemia, because this has been reported in patients with anaemia from other causes (Manfredi, 1965). The normal acid-base status during the acute painful episodes emphasizes the fact that metabolic acidosis is not responsible for the initiation of spontaneous painful crisis. The data presented are in direct contrast to the results of Barreras and Diggs (1964), who noted severe metabolic acidosis in their patients. We cannot at this time offer an adequate explanation for this difference, but there may be geographical variations in the severity of the painful crises. Finally, these results support our belief that alkalis are of little use in either the prevention or the treatment of the painful crisis of sickle-cell anaemia, at least in our population.
We are indebted to Professor J. C. Waterlow, Director of the Tropical Metabolism Research Unit, for his support, and to Dr. Graham Serjeant, who is in charge of the Sickle Cell Clinic of the University Hospital of the West Indies, for referring many of the patients under his care.

One of us (H. H.P.K.) was supported by a grant from the Wellcome Trust.

\section{REFERENCES}

Barreras, L., and Diggs, L. W. (1964). American fournal of the Medical Sciences, 247, 710 .

Diggs, L. W. (1965). American fournal of Clinical Pathology, 44, 1.

Greenberg, M. S., Kass, E. H., and Castle, W. B. (1957). Fournal of Clinical Investigation, 36, 833.

Greenberg, M. S., and Kass, E. H. (1958). Archives of Intermal Medicine, 101,355 .

Hugh-Jones, K., Lehmann, H., and McAlister, J. M. (1964). British Medical fournal, $2,226$.

Manfredi, F. (1965). American Review of Respiratory Disease, 92, 617. Nwokolo, C. (1960). West African Medical fournal, 9, 194

\title{
Operative Treatment of Typhoid Perforation of the Bowel
}

\author{
E. Q. ARCHAMPONG,* B.SC., F.R.C.S., F.R.C.S.ED.
}

British Medical fournal, 1969, 3, 273-276

Summary : One hundred and twenty-one proved cases of typhoid perforation were seen in a three-year period; the incidence of perforation, $17.9 \%$, is the highest recorded. All patients were treated by laparotomy with closure and drainage. The mortality was $29.8 \%$, but $76 \%$ when operation was performed after the fifth day of perforation.

\section{Introduction}

Enteric fever remains a pressing clinical problem in the developing countries of the tropics and ileal perforations from this cause claim high mortalities of about 20 to $40 \%$ (Palmer, 1951 ; Huckstep, 1960). In Ghana the incidence of perforation is unusually high ; Badoe (1966), in a review of 37 cases, recorded an incidence of $15.4 \%$ with a mortality of $30.4 \%$.

Opinion is still divided on the place of surgery in the management of typhoid perforations. Huckstep (1962) advocated conservative measures, and $\mathrm{Li}$ (1963), among others, favoured the operative approach. This paper reports a series of 121 proved cases of typhoid perforation treated operatively. The results were sufficiently encouraging to suggest that a reappraisal of the general attitude to management of this complication of enteric fever is needed.

\section{Methods and Materials}

For this study cases of typhoid perforation admitted to Korle $\mathrm{Bu}$ Hospital during 1966-8 were examined. This involved the pooling of the work of 12 surgeons of varying degrees of seniority and experience, so that the differences due to changing technical skill were eliminated. The study was essentially prospective, and information was obtained by means of a detailed form. To avoid doubt that perforation had actually occurred only cases treated operatively were included in the series: these numbered 121. Eleven patients treated conservatively and nine who died within a few hours of admission before treatment was instituted were excluded.

\section{Results}

There were 789 cases of enteric fever admitted to Korle Bu Hospital over the three-year period; 141 (17.9\%) of these had perforations-a high incidence. There was considerable variation in yearly incidence of the disease, but the proportion with perforations remained unchanged (see Table II) ; 110 (90\%) had perforated on admission, while 11 perforated under medical care.

Age Incidence.-The youngest in the series was a boy of 2 and the oldest a man of 51. Table I shows the breakdown of age incidence. The highest incidence was in the second and third decades ; indeed, all but 15 patients were aged 6 to 34 years. This was perhaps fortunate, since the mortality outside these age limits rises sharply.

\begin{tabular}{|c|c|c|c|c|c|c|}
\hline \multirow{2}{*}{ Age } & \multirow{2}{*}{ Male } & \multirow{2}{*}{ Female } & \multicolumn{2}{|c|}{ Tota } & \multicolumn{2}{|c|}{ Died } \\
\hline & & & No. & $\%$ & No. & $\%$ \\
\hline $\begin{array}{r}\text { Under } 5 \\
5-9 \\
10-19 \\
20-29 \\
30-39 \\
40+\end{array}$ & $\begin{array}{r}6 \\
18 \\
25 \\
20 \\
18 \\
4 \\
91\end{array}$ & $\begin{array}{r}3 \\
10 \\
16 \\
- \\
1\end{array}$ & $\begin{array}{r}9 \\
28 \\
41 \\
20 \\
18 \\
5 \\
121\end{array}$ & $\begin{array}{r}7 \cdot 4 \\
23 \cdot 2 \\
33.9 \\
16.5 \\
14.9 \\
4 \cdot 1 \\
100.0\end{array}$ & $\begin{array}{r}5 \\
10 \\
10 \\
4 \\
4 \\
3 \\
36\end{array}$ & $\begin{array}{l}55 \cdot 6 \\
35 \cdot 7 \\
24 \cdot 4 \\
20 \cdot 0 \\
22 \cdot 2 \\
60 \cdot 0 \\
29 \cdot 8\end{array}$ \\
\hline
\end{tabular}

Sex Incidence.-Of the 121 patients 91 were males and 30 were females, a sex ratio of $3: 1$. Over the age of 20 there was only one woman. This male preponderance is noticeable in several reports (Rowland, $1961 ; \mathrm{Li}, 1963$ ). Examination of the total figures for typhoid shows a female incidence of $35 \%$, so that the apparent difference in perforations is only a reflection of the incidence of typhoid in the sexes as seen in hospital. It may be that fewer females with typhoid fever report to hospital, and then only when seriously ill. This would explain the higher female mortality noted by all workers. In this series female mortality was $33.3 \%$ compared with male figures of $22 \%$.

* Lecturer, Department of Surgery, Ghana Medical School, Accra, 